\title{
Aplicabilidad de las margas de la Cordillera Bética (sur de la provincia de Jaén) para la fabricación de baldosas cerámicas prensadas
}

\author{
Suitability of the Betic Cordillera marly materials \\ for the manufacture of pressed tile
}

\author{
M. Vázquez ${ }^{(*)}, \underline{\text { J. Jiménez-Millán }}{ }^{(*)}$
}

Recepción/Received: 07-III-07

Aceptación/Accepted: 13-V-08

Publicado online/Online publishing: 22-V-08

\section{RESUMEN}

Este trabajo evalúa las posibilidades cerámicas de las margas de la Formación Carbonero para fabricar materiales cerámicos de construcción de alto valor añadido. Litológicamente, la Formación Carbonero está formada por tres miembros: a) Inferior Margoso, b) Intermedio Radiolarítico y c) Superior Turbidítico. Las muestras estudiadas son ricas en filosilicatos (> 39\%) y calcita. Los contenidos en cuarzo y feldespatos son bajos (<27\%). Los filosilicatos mayoritarios son el interestratificado illita-esmectita (14-50\%) y la illita (32-74\%). Caolinita, clorita y paligorskita están en pequeñas cantidades. Los mayores contenidos en $\mathrm{CaO}$ están en las margas de los Miembros Inferior e Intermedio (18-27\%). Las margas molidas presentan similares proporciones granulométricas de las fracciones $<2 \mu \mathrm{m}$ y de la situada entre 2 y $20 \mu \mathrm{m}$. La fracción > $20 \mu \mathrm{m}$ está ausente. La plasticidad de las margas es baja, condicionando que su moldeo deba ser exclusivamente por presión. Los altos valores de contracción lineal y absorción de agua entre 800 y $1.000^{\circ} \mathrm{C}$ son poco apropiados para la industria cerámica. Las mezclas de estos materiales con diferentes proporciones de materiales complementarios permitirían la fabricación de baldosas cerámicas de color claro por prensado.

Palabras clave: Formación Carbonero, baldosas prensadas, materia prima cerámica, materiales de construcción, propiedades tecnológicas.

\section{SUMMARY}

This paper assesses the aptness of Carbonero Formation (in the Spanish province of Jaén) marls for the manufacture of high added value ceramic construction materials. Lithologically speaking, the Carbonero Formation comprises three members: a) a marly lower member; b) a radiolaritic middle member; and c) a turbiditic upper member. The samples studied were rich in phyllosilicates (> 39\%) and calcite. The quartz and feldspar contents were low $(<27 \%)$. The majority phyllosilicates were illite-smectite mixed layers (14-50\%) and illite (32-74\%). Kaolinite, chlorite and palygorskite were also detected. The highest $\mathrm{CaO}$ content was found in the marls in the lower and intermediate members (18-27\%). The particle size distributions of ground marls were similar for the < $2 \mu \mathrm{m}$ and 2-20 $\mu \mathrm{m}$ fractions. The $>20 \mu \mathrm{m}$ fraction was absent. Due to their low plasticity, most Carbonero Formation marls can only be pressure moulded. Their high linear shrinkage and water absorption values when fired at 800 to $1,000{ }^{\circ} \mathrm{C}$ make them poorly suited for use in the ceramic industry. Blends of these marls with different proportions of supplementary materials may be apt for manufacturing light shades of pressed ceramic tile.

Keywords: Carbonero Formation, pressed tiles, ceramic prime material, construction materials, technological properties.

\footnotetext{
(*) Universidad de Granada (Granada, España)

(**) Universidad de Jaén (Jaén, España)
} 


\section{INTRODUCCIÓN}

Las margas son una materia prima que presenta una amplia distribución de afloramiento, gran variedad en la tipología de yacimiento y con importantes reservas de explotación, cuyas propiedades físicas y composición químico-mineralógica sólo permiten la elaboración de productos con especificaciones poco exigentes en el sector cerámico (1-2). Aunque su composición mineralógica y química es muy variada, en la mayor parte de las margas, la ilita es el filosilicato más abundante. Junto a ésta, pueden aparecer cantidades significativas de clorita y esmectita, así como pequeñas proporciones de minerales del grupo de la caolinita. Acompañando a los filosilicatos, se identifica un amplio grupo de minerales. Los más significativos son el cuarzo y los carbonatos, aunque también son descritos muy frecuentemente óxidos, sulfuros y sulfatos. Por tanto, este grupo de materiales se aproxima a las definidas por Fabbri y Fiori (3) como arcillas ilítico-cloríticas, cuyo dato composicional más significativo es su contenido en $\mathrm{Fe}_{2} \mathrm{O}_{3}$ entre el 6 y $8 \%$. Su diversidad composicional y la heterogeneidad de sus tamaños de grano hacen que sus propiedades cerámicas sean muy variadas, si bien, puede afirmarse que, en general, tienden hacia plasticidades bajas y puntos de vitrificación inferiores a los $1.100^{\circ} \mathrm{C}$. Las Zonas Externas de la Cordillera Bética se caracterizan por la presencia de unidades geológicas ricas en materiales carbonatados donde es común la presencia de extensos afloramientos de margas, especialmente en el entorno del núcleo de industria cerámica de Bailén. El objetivo de este trabajo es evaluar la aptitud de estos materiales margosos para la elaboración de cerámica estructural y nuevos productos cerámicos no fabricados en la zona.

\section{MATERIALES DE ESTUDIO}

La selección de los materiales de estudio se realizó valorando el volumen de rocas exclusivamente carbonatadas (calizas y dolomías) en las columnas estratigráficas de las unidades geológicas de las Zonas Externas de la Cordillera Bética y la extensión de sus afloramientos. Siguiendo estos criterios, se eligieron los afloramientos de la Formación Carbonero en el Sur de la provincia de Jaén, ya que es una de las formaciones que presenta un menor número de lechos exclusivamente carbonatados, predominando las rocas margosas que, a priori, parecen tener un contenido lo suficientemente alto de minerales de la arcilla para poder emplearse en la industria cerámica. Desde el punto de vista litoestratigráfico, la Formación Carbonero está compuesta por tres miembros (Figura 1): A) Miembro Inferior Margoso, compuesto por margas grises, con numerosas intercalaciones calcareníticas y conglomeráticas, de edad Barremiense Superior-Aptiense Inferior Basal; B) Miembro Intermedio Radiolarítico, constituido

\section{INTRODUCTION}

Marls are a prime material characterized by abundant and broadly distributed outcrops and a wide variety of deposit types. Their physical properties and chemicalmineralogical composition limit their use by the ceramic industry to products whose specifications are not particularly demanding (1-2). Although marl mineralogical and chemical composition varies widely, illite is the most abundant phyllosilicate in most. Significant proportions of chlorite and smectite may also be present, along with smaller percentages of the kaolinite group minerals. In addition to phyllosilicates, a wide range of other minerals are also found. The most prominent are quartz and carbonates, although oxides, sulphides and sulphates have also been described. Consequently, this group of materials is close to what Fabbri and Fiori (3) define as illite-chloritic clays, whose most significant compositional trait is their $\mathrm{Fe}_{2} \mathrm{O}_{3}$ content, ranging from 6 to $8 \%$. Their compositional diversity and the heterogeneity of their grain sizes lead to variations in their ceramic properties, although as a general rule they tend to exhibit vitrification points of under $1,100{ }^{\circ} \mathrm{C}$ and scant plasticity. The outer areas of the Betic Cordillera are characterized by the presence of geological units rich in carbonate materials, with extensive marl outcrops, particularly in the vicinity of the city of Bailén and its large ceramic industry. The present study aims to evaluate the suitability of these marly materials for manufacturing structural ceramics and new ceramic products not presently produced in the area.

\section{MATERIALS STUDIED}

The materials studied were selected on the grounds of the area of the outcrops and the volume of rocks consisting exclusively of carbonates (limestone and dolostone) in the geological units located in the outer reaches of the Betic Cordillera. The Carbonero Formation outcrops providing the best fit to these criteria were found in the Carbonero Formation. Located in the southern part of the province of Jaén, this formation has both a particularly small number of beds containing carbonated rocks only and a predominance of marly rocks that appear, a priori, to have a sufficiently high clay mineral content for use in the ceramic industry. Lithographically speaking, the Carbonero Formation comprises three members (Figure 1): A) a marly lower member, consisting in grey marls with numerous Upper Barremian-Lower Aptian interbedded calcarenite and conglomeratic layers; B) a radiolaritic intermediate member, with brown or dark grey radiolaritic marl and 


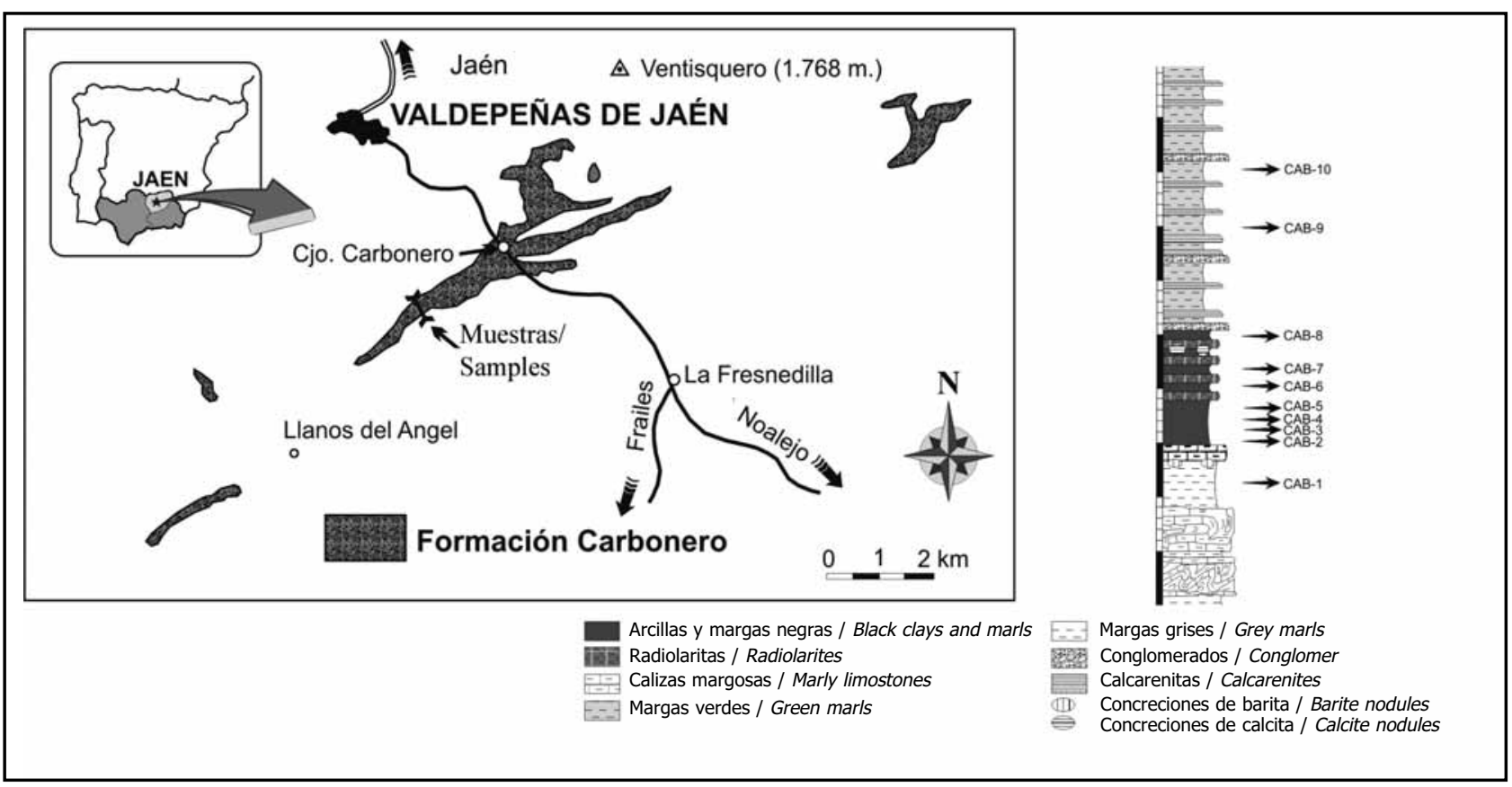

Figura 1. Localización geográfica y columna estratigráfica de la Formación Carbonero.

Figure 1. Carbonero Formation. Location and stratigraphic column.

por margas radiolaríticas de color marrón o gris oscuro, arcillas y margas arcillosas negras o grises de edad Aptiense Inferior; C) Miembro Superior Turbidítico, en el que se diferencia una alternancia de margas y calcarenitas de edad Aptiense Superior-Albiense Basal.

El muestreo de las margas de la Formación Carbonero se centró en los niveles más arcillosos. De esta forma, se seleccionaron cuatro muestras del Miembro Inferior, siete del Miembro Intermedio y dos del Miembro Superior. La mayor concentración del muestreo en el Miembro Intermedio es debida al pequeño número de niveles carbonatados y la abundancia de materiales arcillosos, lo cual hace que este tramo resulte de gran interés para una posible explotación industrial.

\section{TÉCNICAS EXPERIMENTALES}

Se ha realizado una caracterización composicional de todas las muestras mediante análisis mineralógicos y químicos. La composición mineralógica ha sido determinada mediante el uso de difracción de rayos $X$ (DRX, Siemens D-5000 con filtro de Ni, radiación CuK $35 \mathrm{KV}$ y 34 $\mathrm{mA}$ ). Los análisis mineralógicos cualitativos se han llevado a cabo en la muestra total molida y en la fracción $<2 \mu \mathrm{m}$. La mineralogía de arcillas fue determinada en agregados orientados (natural, calentados a $550{ }^{\circ} \mathrm{C}$ durante $2 \mathrm{~h}$ y solvatados en etilenglicol y dimetilsulfóxido). Para los análisis semi-cuantitativos de la muestra total se han usado los parámetros calculados para el difractómetro Siemens D-5000 de la Universidad de black or grey Lower Aptian clay and clayey marl; and C) a turbiditic upper member, with alternating Upper AptianLower Albian marls and calcarenites.

Sampling focused on the most clayey layers in the Carbonero Formation. Four marl samples were taken from the lower member, seven from the intermediate member and two from the upper member. Sampling density was greatest in the intermediate member because of its small number of carbonated layers and the abundance of clayey material, making this unit particularly attractive for possible industrial quarrying.

\section{EXPERIMENTAL}

Mineralogical and chemical analyses were conducted on all the samples. Mineralogical composition was determined with $X$-ray diffraction (XRD) techniques (Siemens D-5000 with a Ni filter, $35 \mathrm{KV}$ and $34 \mathrm{~mA} \mathrm{Cu}$ Koradiation). Qualitative mineralogical analyses were conducted on the ground bulk sample as well as on the $<2 \mu \mathrm{m}$ fraction. Clay mineralogy was determined in oriented aggregates (untreated, heated at $550{ }^{\circ} \mathrm{C}$ for two hours and solvated in ethylenglycol and dimethylsulphoxide). The parameters calculated for the University of Jaén's Siemens D-5000 diffractometer were used for the semi-quantitative analyses of the bulk sample. The mineral proportions in the clay were 
Jaén. En el caso del cálculo de la proporción de minerales de la arcilla se empleó el conjunto de factores recogido por Dinelli y Tateo (5), después de corregir estos parámetros para su utilización en difractómetros de rendija automática. En el caso del interestratificado ilita/esmectita rico en esmectita se ha utilizado el mismo que el de la esmectita, y para aquéllos ricos en ilita se ha calculado un poder reflectante basado en la relación de intensidades de los picos situados a 4,9 $\AA$ en condiciones naturales y a $9,4 \AA$ en etilenglicol. Por otra parte, los análisis químicos de los elementos mayoritarios han sido realizados mediante espectrometría de fluorescencia de rayos X (Philips PW 1404/10) en perlas de fusión.

Algunas muestras estudiadas han sido seleccionadas para su caracterización tecnológica (CAB-1-4, CAB-5, CAB-7, CAB-13). Los materiales fueron sometidos a un proceso inicial de molienda en molino de mandíbulas sólo durante 10 segundos con el objetivo de realizar una disgregación de la materia que altere lo menos posible la distribución granulométrica de la muestra. El resto del trabajo de laboratorio se centró en tamizado a través de un tamiz de luz de malla $<100 \mu \mathrm{m}$, análisis granulométricos (Galai CIS-1), desagregación y humectación (4-6\% agua), prensado con una prensa hidráulica $\left(300 \mathrm{~kg} / \mathrm{cm}^{2}\right)$, secado (24 $\mathrm{h}$ a $\left.110^{\circ} \mathrm{C}\right)$, y cocción en un horno eléctrico (26-36 h, 800 a $1.000{ }^{\circ} \mathrm{C}$ de temperatura máxima). También, la contracción lineal, la absorción de agua (EN 99), la porosidad y la densidad aparente han sido medidas en las piezas cocidas. La contracción lineal y los límites de Atterberg (límite líquido, LL, y límite plástico, $\mathrm{PL}$, según UNE 7-377-75 y UNE 103-104-93, respectivamente) fueron medidos en las piezas secas. Además, se empleó la técnica de difracción de rayos $X$ (DRX) para determinar las fases de alta temperatura en las piezas cocidas.

\section{CARACTERÍSTICAS COMPOSICIONALES}

\subsection{Composición mineralógica}

Los resultados de los análisis de DRX (Tabla 1 ) revelan que las margas estudiadas son ricas en filosilicatos (>39\%). No obstante, es necesario señalar la presencia de cantidades considerables de calcita, más elevadas en las margas de los Miembros Inferior e Intermedio (hasta $44 \%$ ), que en las del Miembro Superior (en torno al $20 \%$ ). Sin embargo, hay que destacar que en el Miembro Intermedio se localiza la muestra más pobre en calcita de las analizadas (14\%, CAB 7). Por otra parte, el contenido en cuarzo y feldespatos es generalmente bajo (cuarzo + feldespato $<23 \%$ ). La proporción (cuarzo + feldespatos)/filosilicatos se mantiene aproximadamente constante $(0,40)$ a lo largo de toda la formación. Las radiolaritas del Miembro Intermedio (CAB-10 y CAB-11) son ricas en filosilicatos (67 y $64 \%$, respectivamente) y calculated with the factors reported by Dinelli and Tateo (5), corrected for use with automatic slit diffractometers. For the smectite-rich illite/smectite mixed layer, the factor used was the same as for smectite, and for the illite-rich layers, reflective power was calculated based on the ratio of the peak intensities at $4.9 \AA$ in the untreated samples and $9.4 \AA$ in the ethylenglycol samples. Moreover, the majority elements were analyzed with $X$-ray fluorescence spectrometry (Philips PW 1404/10) on glass beads.

Some of the samples studied were selected for technological characterization (CAB-1-4, CAB-5, CAB-7, $C A B-13)$. These materials were initially ground in a jawbreaker for only 10 seconds to disaggregate the matter while altering the particle size distribution of the sample as little as possible. The rest of the laboratory work involved sieving with a mesh size < $100 \mu \mathrm{m}$, particle size analysis (Galai CIS-1), disaggregation and moistening (4-6\% water), pressing in a hydraulic press $\left(300 \mathrm{~kg} / \mathrm{cm}^{2}\right)$, drying $\left(24 \mathrm{~h}\right.$ at $\left.110^{\circ} \mathrm{C}\right)$ and firing in an electric kiln (26-36 $h$ at a temperature of 800 to $1,000^{\circ} \mathrm{C}$ ). Linear shrinkage, water absorption (European standard EN 99), porosity and bulk density were also measured in the fired pieces. Both linear shrinkage and the Atterberg limits (liquid limit, $L L$ and plastic limit, PL, as per Spanish standards UNE 7-377-75 and UNE 103104-93, respectively) were measured in the dry pieces. $X$-ray diffraction (XRD) was also used to determine the high temperature phases in the fired pieces.

\section{COMPOSITION}

\subsection{Mineralogical composition}

The results of XRD analysis (Table 1 ) revealed that the marls studied were rich in phyllosilicates (>39\%). Nonetheless, substantial proportions of calcite were also present, which were higher in the lower and intermediate member marls (up to 44\%) than in the upper member materials (around 20\%). The sample with the lowest percentage of calcite $(14 \%, C A B-7)$ was taken from the intermediate member, however. Moreover, the quartz and feldspar contents were generally low (quartz + feldspar < 23\%). The (quartz + feldspar)/phyllosilicate ratio was approximately constant $(0.40)$ throughout the formation. The radiolarite in the intermediate member (CAB-10 and $C A B-11)$ had high phyllosilicate (67 and $44 \%$, respectively) and quartz (around $35 \%$ ) contents. The mineralogical analysis conducted failed to detect the 
Tabla 1 / Table 1

Composición mineralógica de las muestras estudiadas de la Fm. Carbonero (\% en peso). Mineralogical composition (weight, \%) of Carbonero Formation samples.

\begin{tabular}{|c|c|c|c|c|c|c|c|c|c|}
\hline \multicolumn{5}{|c|}{ Muestra total en polvo / Bulk powder sample } & \multicolumn{5}{|c|}{$\begin{array}{l}\text { Filosilicatos de la fracción }<2 \mu \mathrm{m} \text { en A.O. I Phyllosilicates } \\
\text { in }<2 \mu \mathrm{m} \text { fraction in A.O. }\end{array}$} \\
\hline Phy & Fds & Qtz & Cc & III/Sm & $\mathrm{Chl} / \mathrm{Sm}$ & KIn & III & Chl & \\
\hline \multicolumn{10}{|c|}{ Miembro inferior / Lower member } \\
\hline 52 & $<5$ & 10 & 35 & 76 & - & $<5$ & 15 & $<5$ & CAB-1- 4 \\
\hline \multicolumn{10}{|c|}{ Miembro intermedio / Intermediate member } \\
\hline 57 & $<5$ & 10 & 29 & 23 & - & 40 & 23 & 14 & CAB-5 \\
\hline 39 & $<5$ & 13 & 44 & 88 & - & $<5$ & 6 & $<5$ & CAB-6 \\
\hline 65 & $<5$ & 17 & 14 & - & - & 12 & 87 & $<5$ & CAB-7 \\
\hline 40 & $<5$ & 17 & 42 & - & - & 39 & 57 & $<5$ & CAB-8 \\
\hline 47 & $<5$ & 17 & 33 & - & - & 54 & 27 & 19 & CAB-9 \\
\hline 67 & $<5$ & 31 & - & 79 & - & 13 & 7 & $<5$ & CAB-10 \\
\hline 64 & $<5$ & 34 & - & - & 73 & 9 & 16 & $<5$ & CAB-11 \\
\hline \multicolumn{10}{|c|}{ Miembro superior / Upper member } \\
\hline 52 & $<5$ & 22 & 21 & - & - & 48 & 39 & 13 & CAB-12 \\
\hline 59 & 8 & 10 & 23 & 88 & - & 6 & 5 & $<5$ & CAB-13 \\
\hline
\end{tabular}

Phy = filosilicatos. Fds = feldespatos. Qtz = cuarzo. $\mathrm{Cc}=$ calcita. Il/Sm = interestratificado ilita/esmectita; Chl/Sm = interestratificado clorita/esmectita; Kln = caolinita. $\mathrm{Ill}=$ ilita. $\mathrm{Chl}=$ clorita. A.O. = agregado orientado $/$ Phy = phyllosilicates. Fds $=$ feldspars. Qtz $=$ quartz. $\mathrm{Cc}=$ calcita. $\mathrm{Il} / \mathrm{Sm}=$ illite/smectite mixed layers; $\mathrm{Chl} / \mathrm{Sm}=$ chlorite/smectite layers; $\mathrm{Kln}=$ kaolinite. $\mathrm{Ill}=\mathrm{Illite} . \mathrm{Chl}=$ chlorite. A.O. $=$ oriented aggregate.

cuarzo (alrededor del 35\%). En los análisis mineralógicos realizados no han sido detectadas las reflexiones características de ópalo CT ni de sílice biogénica, tales como las descritas previamente por López Galindo (6) en la fracción 2-20 $\mu \mathrm{m}$ de esta Formación. Sin embargo, a la base de esta secuencia se ha identificado una asociación de radiolarios característica del Aptiense Inferior (7).

Los filosilicatos mayoritarios son la ilita y el interestratificado ilita/esmectita. Los interestratificados ilita/esmectita se han reconocido por la presencia de las reflexiones (001/002) y (002/003) en la región comprendida entre 9 y $17,702 \theta$ en los diagramas de etilenglicol. De acuerdo con Moore y Reynolds (4), se han identificado dos tipos de interestratificados ilita/esmectita: a) interestratificados ricos en ilita, con la reflexión (001/002) a $10^{\circ}$ y la $(002 / 003)$ a $16^{\circ} 2 \theta$; y b) interestratificados enriquecidos en esmectita, los cuales presentan la reflexión a $(001 / 002)$ a 90 y la $(002 / 003)$ a $17^{\circ} 2 \theta$. Por otra parte, los interestratificados clorita/esmectita han sido reconocidos por la reflexión situada entre 10 y $12^{\circ} 2 \theta$ en el diagrama de etilenglicol.

Se han identificado dos tipos de interestratificados ilita/esmectita, una rica en ilita y la otra en esmectita. Las muestras basales de la secuencia (CAB-1-4 y CAB5) presentan cantidades altas de interestratificado ilita/esmectita rico en esmectita (76 y $23 \%$, respectivamente). No obstante, en las muestras CAB-10 y $C A B-13$, el interestratificado ilita/esmectita con altas proporciones de ilita está presente en cantidades importantes (79 y $88 \%$ ). El contenido en ilita del Miembro Intermedio varía entre un $6 \%$ y un $27 \%$ para la reflections characteristic of opal-CT or biogenic silica described by López Galindo (6) in the 2-20 $\mu \mathrm{m}$ fraction of this formation. By contrast, a radiolarian association characteristic of the Lower Aptian was identified at the bottom of this sequence (7).

The majority phyllosilicates were illite and illite/smectite mixed layers. The latter were identified due to the presence of (001/002) and (002/003) reflections in the

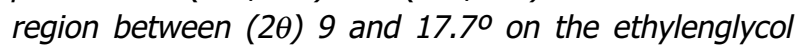
diagrams. According to Moore and Reynolds (4), two types of illite/smectite mixed layers have been identified: a) illite-rich mixed layers, with a (001/002) reflection at

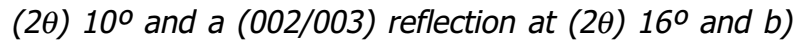
smectite-rich mixed layers, with (001/002) reflections at

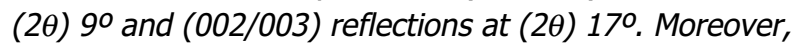
the chlorite/smectite mixed layers were identified by the reflection positioned between (20) 10 and $12^{\circ}$ on the ethylenglycol diagram.

Two types of illite/smectite mixed layers were identified, one rich in illite and the other in smectite. The bottom samples for the sequence (CAB-1-4 and $C A B-5)$ exhibited high proportions of smectite-rich illite/smectite mixed layers (76 and 23\%, respectively). Nonetheless, large amounts of the high illite content illite-smectite mixed layer were present in samples $C A B-10$ and $C A B-$ 13 (79 and 88\%). While the illite content in the intermediate member ranged from 6 to $27 \%$ in most of the samples studied, samples $C A B-7$ and $C A B-8$ had 
mayoría de las muestras estudiadas. Sin embargo, las muestras $\mathrm{CAB}-7$ y CAB-8 están enriquecidas en este mineral ( 87 y $57 \%$ ). Las margas de los Miembros Inferior y Superior tienen cantidades de ilita inferiores al $15 \%$, excepto la muestra $C A B-12$ que contiene un $39 \%$. La clorita está presente en bajas concentraciones (< 19\%) a lo largo de toda la columna estratigráfica. Sólo en la muestra CAB-11 se ha detectado interestratificado clorita/esmectita (73\%). También se han reconocido pequeñas reflexiones a $10,6 \AA$ en las muestras $C A B-$ 6 y $C A B-12$ que han sido interpretadas como debidas a la existencia de trazas de paligorskita.

La composición mineralógica de los materiales de la Formación. Carbonero ha sido representada en el diagrama ternario propuesto por Dondi et al. (8) para las materias primas usadas en la fabricación de materiales cerámicos de la construcción en Italia (Figura 2). Su contenido en carbonatos difiere notablemente del de las arcillas usadas para pavimentos y revestimientos cerámicos (Figura 3). Sólo la muestra CAB-12 del Miembro Superior se proyecta dentro del intervalo composicional de materias primas aptas para fabricar gres rojo. Además, las muestras de radiolaritas (CAB-10 y CAB-11) se sitúan próximas al área especificada para gres blanco. much higher proportions of this mineral (87 and 57\%). The lower and upper member marls had illite contents of under $15 \%$, except sample $C A B-12$, where the figure rose to $39 \%$. Only low concentrations of chlorite (<19\%) were found throughout the stratigraphic column. Chlorite/smectite mixed layers (73\%) were found in sample $C A B-11$ only. The small reflections detected at $10.6 A$ in samples $C A B-6$ and $C A B-12$ were interpreted to be due to the existence of traces of paligorskite.

In Figure 2, the mineralogical composition of the Carbonero Formation materials is depicted on the ternary diagram proposed by Dondi et al. (8) for prime materials used to manufacture ceramic construction products in Italy. Their carbonate content differs substantially from the amount in clays used for ceramic flooring and surfacing (Figure 3). Only upper member sample CAB-12 falls within the compositional interval of prime materials apt for manufacturing red porcelain tile. The radiolarite samples (CAB-10 and $C A B-11)$, in turn, are positioned close to the area specified for white porcelain tile.

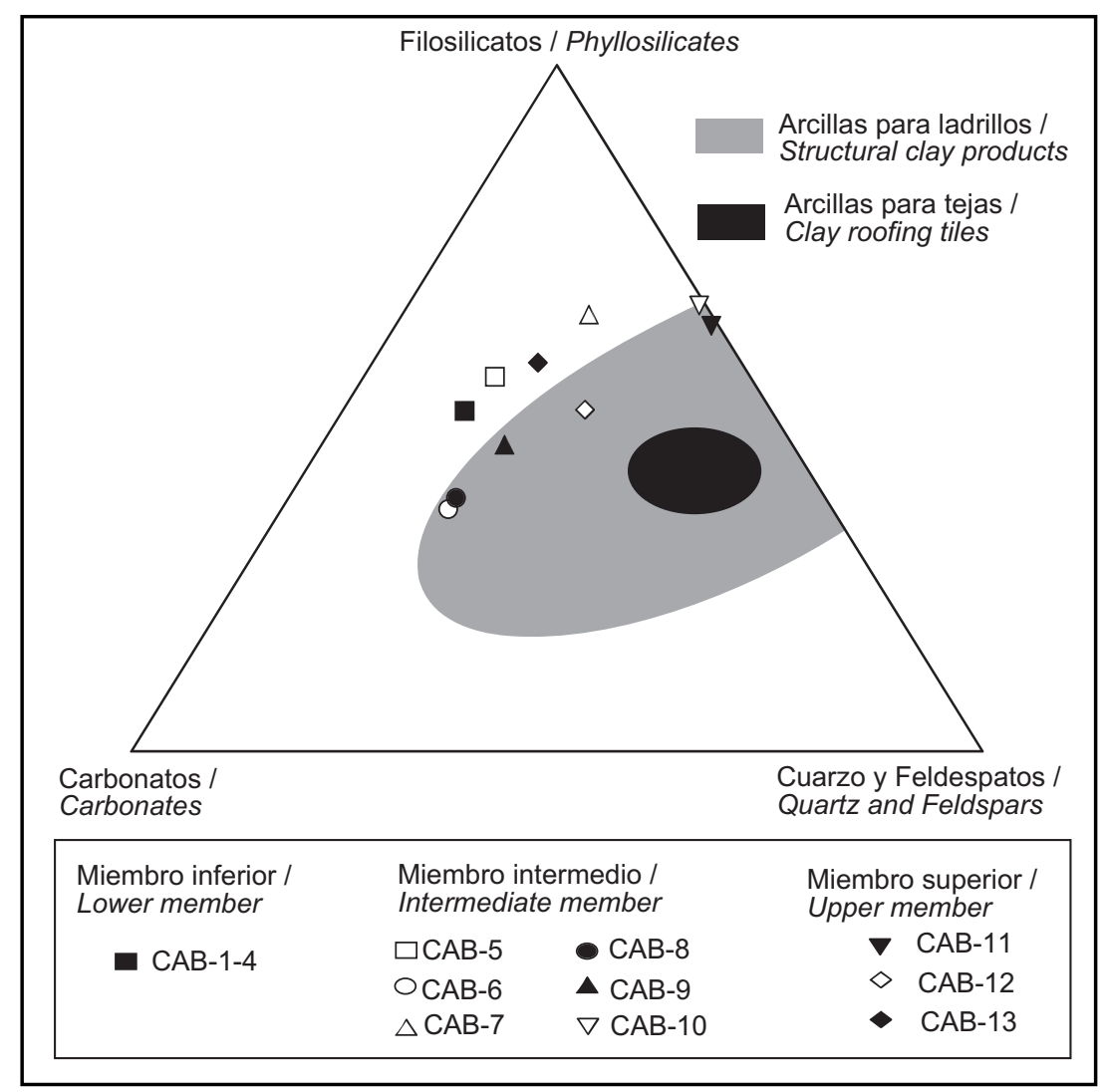

Figura 2. Comparación de la composición mineralógica de las muestras estudiadas de la Formación Carbonero con las arcillas usadas para la fabricación de productos cerámicos en Italia (8).

Figure 2. Comparison of the mineralogical compositions of the Carbonero Formation samples studied and the clays used to manufacture ceramic products in Italy (8). 


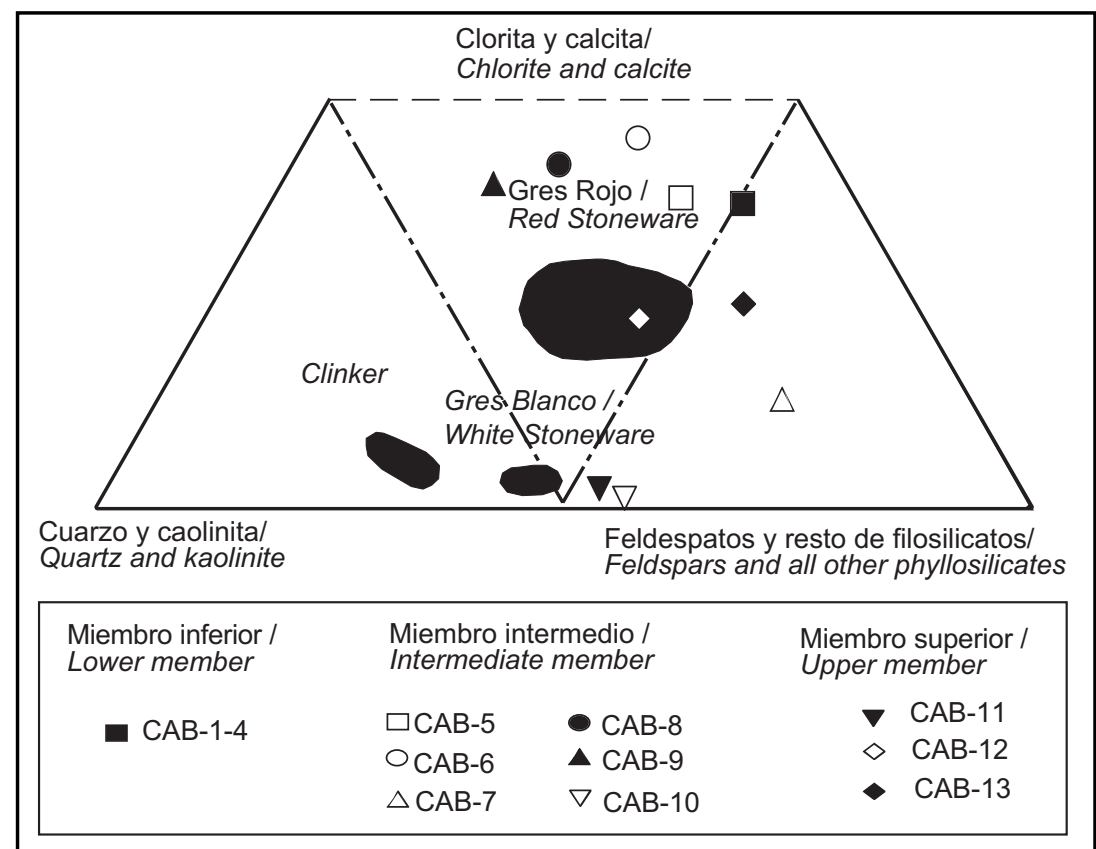

Figura 3. Comparación de la composición mineralógica de las muestras estudiadas de la Formación Carbonero con los campos tradicionales de pavimentos y revestimientos en Italia (8).

Figure 3. Comparison of the mineralogical compositions of the Carbonero Formation samples studied and traditional Italian ceramic floor and wall tiles (8).

\subsection{COMPOSICIÓN QUÍMICA}

Se realizaron análisis químicos de las margas de los tres miembros (Tabla 2). De acuerdo con su proporción de calcita, el contenido en Ca de las muestras del Miembro Superior (13,5\% de $\mathrm{CaO}$ ) es generalmente más bajo que el de las margas de los Miembros Inferior e Intermedio (18-27\%). Sólo la muestra CAB-7 del Miembro Intermedio presenta concentraciones de $\mathrm{CaO}$ similares a las del Miembro Superior. La menor cantidad de $\mathrm{CaO}$ de estas rocas se correlaciona con los mayores valores de $\mathrm{SiO}_{2}$ $(44,5 \%)$ y $\mathrm{Al}_{2} \mathrm{O}_{3}(14,6 \%)$. El enriquecimiento en $\mathrm{K}$ de las muestras pobres en $\mathrm{Ca}$, refleja el carácter más ilítico de su composición mineralógica. Los valores de $\mathrm{Fe}, \mathrm{Mg}$ y $\mathrm{Na}$ son bajos y bastante homogéneos a lo largo de toda la Formación.

\subsection{CHEMICAL COMPOSITION}

Chemical analyses were conducted on the marls from all three members (Table 2). Measured in terms of calcite proportions, the Ca content in the upper member samples $(13.5 \% \mathrm{CaO})$ was generally smaller than in the lower and intermediate member marls (18-27\%). The exception was intermediate member sample $C A B-7$, whose $\mathrm{CaO}$ concentrations were similar to the calcium oxide content in the upper member. The lower amounts of $\mathrm{CaO}$ in these rocks was correlated to the higher $\mathrm{SiO}_{2}$ (44.5\%) and $\mathrm{Al}_{2} \mathrm{O}_{3}(14.6 \%)$ values. The high $\mathrm{K}$ content in low Ca samples reflected their illitic mineralogy. The values for $\mathrm{Fe}, \mathrm{Mg}$ and $\mathrm{Na}$ were low and fairly uniform across the entire Formation.

Tabla 2 / Table 2

Composición química de las muestras estudiadas de la Formación Carbonero (\% en peso). Chemical composition (weight, \%) of Carbonero Formation samples.

\begin{tabular}{|c|c|c|c|c|c|c|c|c|c|c|c|}
\hline & $\mathbf{S i O}_{\mathbf{2}}$ & $\mathbf{A l}_{\mathbf{2}} \mathbf{O}_{\mathbf{3}}$ & $\mathbf{F e}_{\mathbf{2}} \mathbf{O}_{\mathbf{3}}$ & $\mathbf{M n O}$ & $\mathbf{M g O}$ & $\mathbf{C a O}$ & $\mathbf{N a}_{\mathbf{2}} \mathbf{O}$ & $\mathbf{K}_{\mathbf{2}} \mathbf{O}$ & $\mathbf{T i O}_{\mathbf{2}}$ & $\mathbf{P}_{\mathbf{2}} \mathbf{O}_{\mathbf{5}}$ \\
\hline \multicolumn{8}{|c|}{ Miembro inferior / Lower member } \\
\hline $\mathrm{CAB}-1-4$ & 32.6 & 9.31 & 3.49 & 0.04 & 1.15 & 25.9 & 0.49 & 1.98 & 0.40 & 0.09 \\
\hline \multicolumn{8}{|c|}{ Miembro intermedio / Intermediate member } \\
\hline CAB-5 & 40.23 & 12.13 & 4.04 & 0.04 & 1.38 & 18.73 & 0.36 & 2.52 & 0.53 & 0.07 \\
\hline CAB-7 & 45.59 & 14.48 & 3.89 & 0.04 & 1.43 & 13.93 & 0.28 & 2.69 & 0.66 & 0.07 \\
\hline CAB-8 & 30.59 & 7.96 & 3.06 & 0.17 & 1.10 & 27.20 & 0.21 & 1.48 & 0.33 & 0.10 \\
\hline \multicolumn{8}{|c|}{ Miembro superior / Upper member } & & & \\
\hline CAB-13 & 44.50 & 14.6 & 4.08 & 0.03 & 1.45 & 13.5 & 0.46 & 3.02 & 0.60 & 0.06 \\
\hline
\end{tabular}


Teniendo en cuenta los datos de composición química publicados por Fabbri y Fiori (3), Fiori et al. (9), y Fabbri y Dondi (10) de materias primas empleadas para la producción de baldosas cerámicas (Figura 4), las muestras CAB-5, CAB-7 y CAB-13 presentan una composición similar a la de las arcillas utilizadas para la fabricación de mayólica. Sin embargo, las muestras CAB-1-4 del Miembro Inferior y $\mathrm{CAB}-8$ del Miembro Intermedio presentan un exceso de $\mathrm{CaO}$ y $\mathrm{MgO}$ para elaborar este tipo de producto.
Further to the chemical composition data published by Fabbri and Fiori (3), Fiori et al. (9), and Fabbri and Dondi (10) on the prime materials used to manufacture ceramic tile (Figure 4), samples $C A B-5, C A B-7$ and $C A B-13$ exhibited a composition similar to the composition of the clays used to make majolica. Lower member samples CAB-1-4 and intermediate member sample CAB-8 contained too much $\mathrm{CaO}$ and $\mathrm{MgO}$ to be used for manufacturing that product, however.

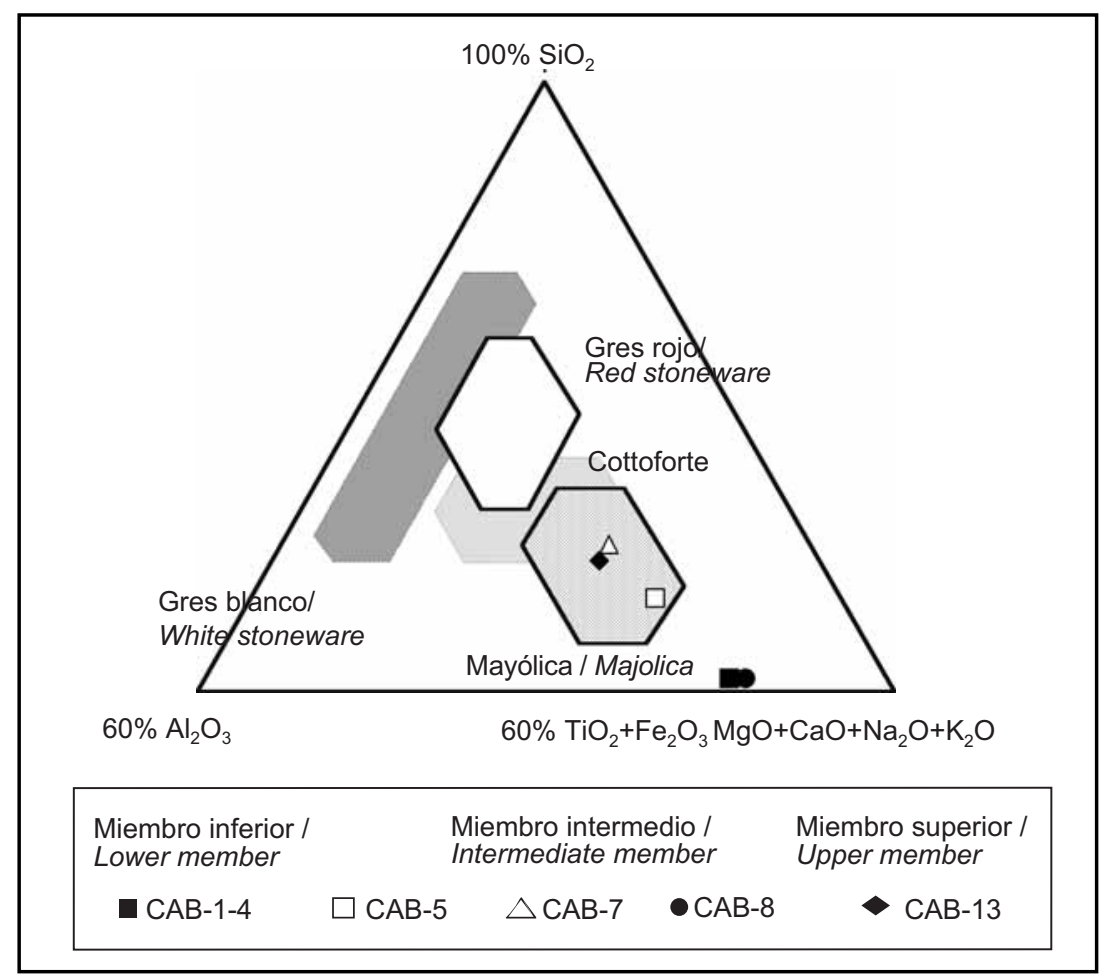

Figura 4. Comparación de la composición química de las margas de la Formación Carbonero con las materias primas usadas tradicionalmente en Italia para la fabricación de baldosas cerámicas $(3,9$ y 10$)$.

Figure 4. Comparison of the chemical composition of Carbonero Formation marls and the prime materials traditionally used in Italy to manufacture ceramic tiles (3, 9 and 10).

\section{PROPIEDADES TECNOLÓGICAS}

\subsection{Distribución granulométrica}

La Figura 5 revela que la granulometría de los materiales estudiados es similar a la de las arcillas usadas en la fabricación de cerámica estructural en Italia. Teniendo en cuenta el diagrama de Winkler (11) (Figura 6), la mayoría de estas margas cretácicas presentan una distribución granulométrica similar a la de las materias primas utilizadas en la fabricación de tejas y piezas perforadas. La distribución de tamaño de grano de los materiales estudiados también es parecida a la de otras que se utilizan para fabricar baldosas y pavimentos cerámicos en la industria de Sassuolo (Italia) (ver Dondi (12)).

\section{TECHNOLOGICAL PROPERTIES}

\subsection{Particle size distribution}

Figure 5 shows the similarity in the particle size distribution for the materials studied and the clays used to manufacture structural ceramics in Italy. According to the Winkler diagram (11) (Figure 6), the particle size distribution in most of these Cretacean marls was similar to the distribution in the prime materials used to manufacture roof and perforated tiles. The grain size distribution of the materials studied was also similar to the distribution found in materials employed by the Sassuolo, Italy industry to make ceramic tiles and flooring (see Dondi (12)). 


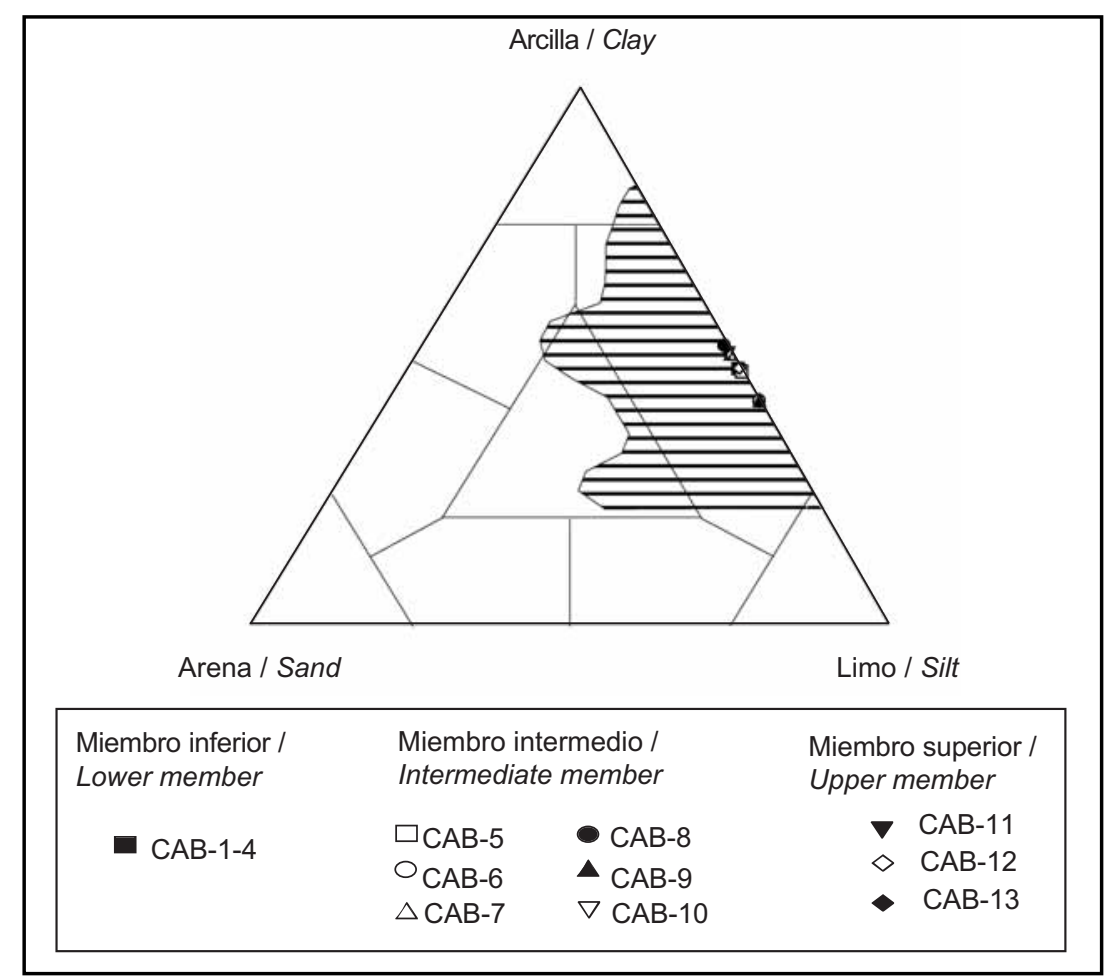

Figura 5. Clasificación de las margas estudiadas de la Formación Carbonero basada en los ratios de arena-limo-arcilla. El área rayada representa la distribución granulométrica más frecuente de las materias primas italianas utilizadas para la fabricación de productos cerámicos estructurales (12).

Figure 5. Classification of Carbonero Formation marls based on sand-loam-clay ratios. The lines represent the most common particle size distribution for the Italian prime materials used to manufacture structural ceramic products (12).

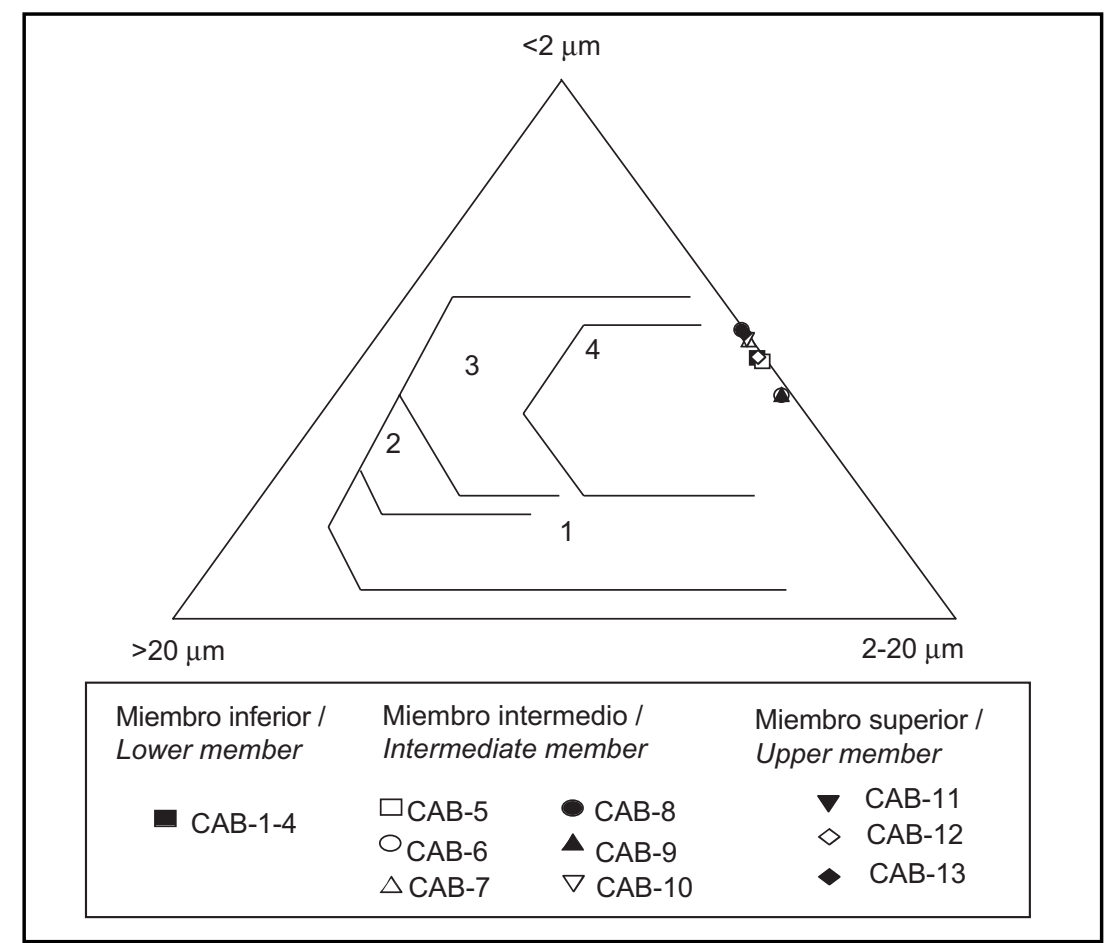

Figura 6. Distribución granulométrica de las margas de Formación Carbonero en el diagrama de Winkler (11). (1) Ladrillo común; (2) ladrillo perforado verticalmente; (3) tejas y bloques ligeros; (4) bloques y ladrillos delgados.

Figure 6. Particle size distribution of Carbonero Formation marls on the Winkler diagram (11). (1) Common brick; (2) vertically perforated brick; (3) lightweight roof tiles and blocks; (4) thin blocks and brick. 


\subsection{Propiedades en crudo}

Las margas de la Formación Carbonero tienen generalmente baja plasticidad, presentando valores de índice plástico moderados (8,2-16,1\%) (Figura 7). La mayoría de las muestras estudiadas presentan valores bajos de límite líquido (28-43\%), mientras que el límite plástico es moderado $(19,4-30,6 \%)$. Debido a su pobre comportamiento plástico, casi todos los materiales de la secuencia son exclusivamente aptos para el moldeo por presión (Figura 7). Sólo la muestra $C A B-7$ del Miembro Intermedio tiene suficiente plasticidad para el moldeo por extrusión, debido, posiblemente, a su alto contenido en filosilicatos. En este sentido, la representación en el diagrama de Bain y Highley (13) (Figura 8) revela que ésta es la única muestra que presenta propiedades aceptables de moldeo.

Por otra parte, la contracción lineal en seco respecto al estado húmedo de las muestras seleccionadas para la cocción varía entre 0,36 y 0,77\% (Tabla 3).

\subsection{Raw properties}

Plasticity in the Carbonero Formation marls is generally low and its plastic indices moderate (8.2-16.1\%) (Figure 7). Most of the samples studied had low liquid limit values (28-43\%) and a moderate plastic limit (19.4$30.6 \%$ ). Due to this poor plasticity, nearly all the materials in the sequence were found to be suitable for pressure moulding only (Figure 7). The sole sample plastic enough for extrusion moulding was intermediate member $C A B-7$, due perhaps to its high phyllosilicate content. Note that according to the Bain and Highley diagram (13) in Figure 8, this was the only sample with acceptable moulding properties.

Furthermore, linear shrinkage in the dry samples selected for firing ranged from 0.36 to $0.77 \%$ (compared to the moist samples) (Table 3).

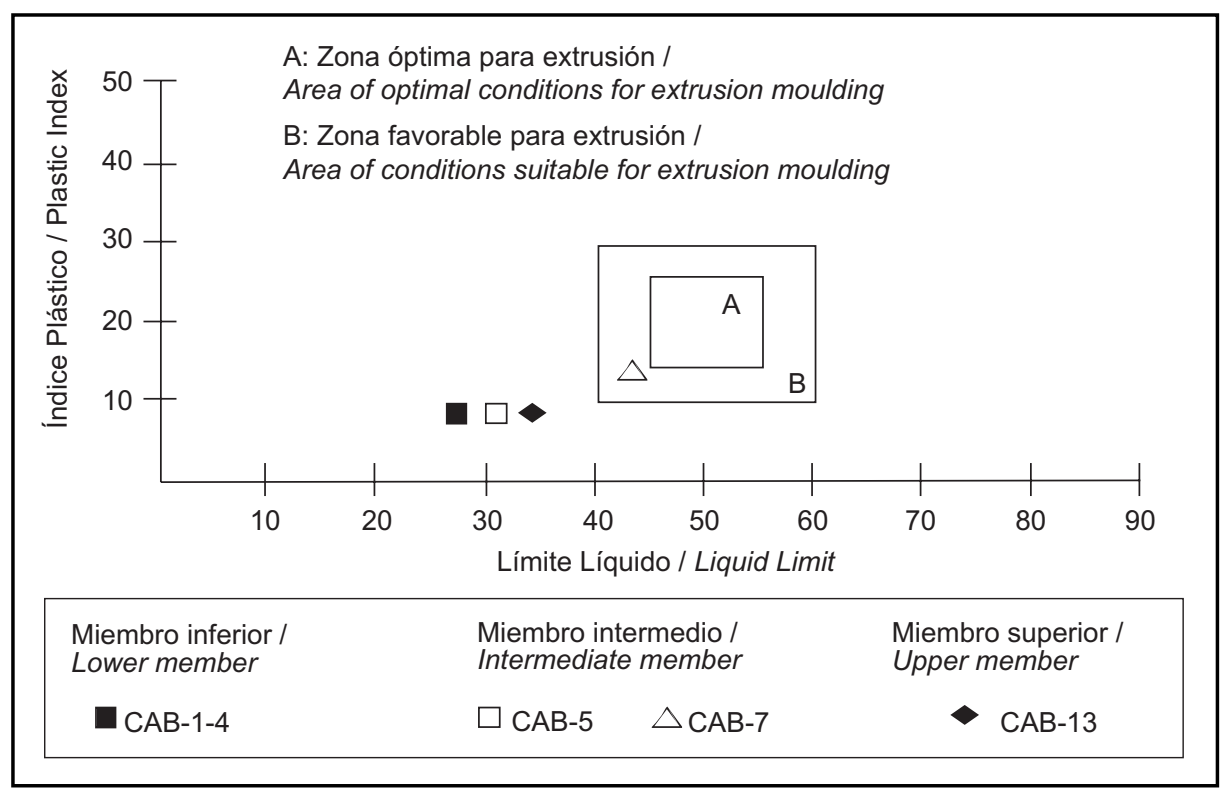

Figura 7. Diagrama de Casagrande de las muestras estudiadas de la Formación Carbonero. Figure 7. Casagrande chart of the Carbonero Formation samples.

Tabla 3 / Table 3

Valores de contracción lineal de las muestras secas (\%). Linear shrinkage in dry simples (\%).

\begin{tabular}{|c|c|}
\hline & C.L./L.S. \\
\hline \multicolumn{2}{|c|}{ Miembro inferior/ Lower member } \\
\hline CAB-1-4 & 0.43 \\
\hline \multicolumn{2}{|c|}{ Miembro intermedio / Intermediate member } \\
\hline CAB-5 & 0.36 \\
\hline CAB-7 & 0.77 \\
\hline Miembro superior/ Upper member \\
\hline CAB-13 & 0.69 \\
\hline
\end{tabular}

C.L. = Contracción lineal / D.S. = Linear shrinkage 


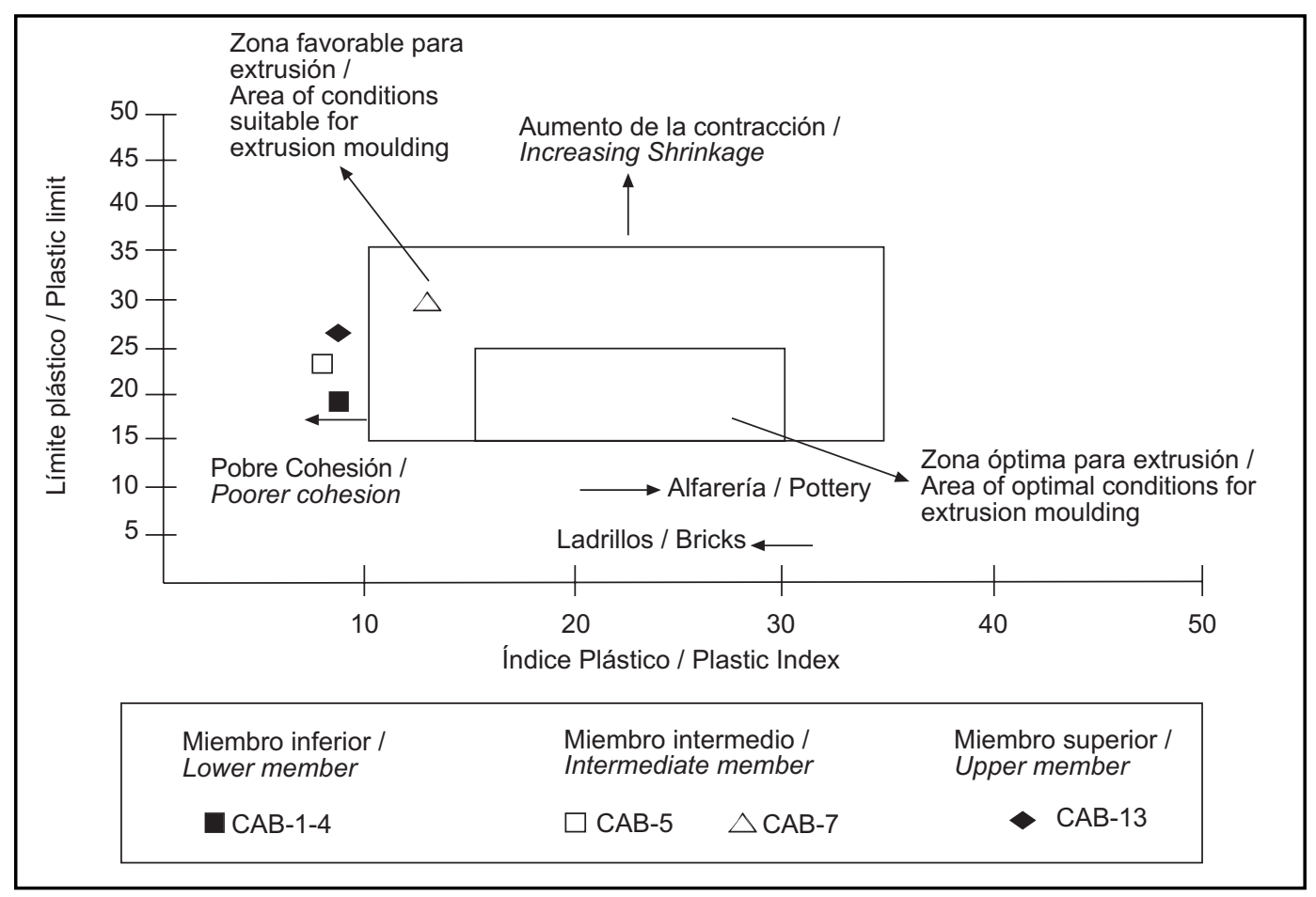

Figura 8. Diagrama de manejabilidad de las muestras estudiadas de la Formación Carbonero. Figure 8. Workability chart of the Carbonero Formation samples.

\subsection{PROPIEDADES DE COCCIÓN}

Los ensayos de cocción han sido realizados en el intervalo de temperatura comprendido entre 800 y 1.000 ${ }^{\circ} \mathrm{C}$. Las piezas cerámicas presentan valores elevados de contracción lineal y de absorción de agua (Figura 9). Para este intervalo de temperatura, la contracción lineal se sitúa entre el 3,5\% y el $8 \%$ cuando la absorción de agua oscila entre el 10 y $25 \%$. Los valores de densidad aparente son relativamente homogéneos $(1,15-$ $\left.1,60 \mathrm{~g} / \mathrm{cm}^{3}\right)$. La absorción de agua de las piezas cocidas se encuentra influenciada por la composición y la distribución granulométrica de las materias primas. Los valores más elevados pertenecen a las muestras más ricas en carbonatos, mientras que los menores se localizan en las margas con mayor contenido en elementos alcalinos y enriquecidos en la fracción $<2 \mu \mathrm{m}$. En cualquier caso, la elevada contracción lineal y absorción de agua de las margas cocidas entre 800 y $1.000{ }^{\circ} \mathrm{C}$ desaconsejan su empleo para la elaborar productos cerámi$\cos (10)$.

Con el objetivo de mejorar las propiedades de secado y cocción, se realizaron las siguientes mezclas con diferentes proporciones de cuarzo y feldespatos comerciales (Figura 10): A) CAB-1-4 + 25\% feldespatos $+5 \%$ cuarzo; B) CAB-5 + $15 \%$ feldespatos $+15 \%$ cuarzo; C) CAB-7 $+15 \%$ feldespatos $+5 \%$ cuarzo; D) CAB-13 + $15 \%$ feldespatos $+15 \%$ cuarzo. En las muestras $C A B-$ 5 y $\mathrm{CAB}-13$ se introdujo un $15 \%$ de feldespatos y un

\subsection{FIRING PROPERTIES}

The firing trials were conducted at temperatures ranging from 800 to $1,000{ }^{\circ} \mathrm{C}$. The ceramic pieces exhibited high linear shrinkage and water absorption values (Figure 9). In this temperature interval, linear shrinkage was from 3.5 to $8 \%$ while water absorption ranged from 10 to $25 \%$. Bulk density values were relatively uniform $\left(1.15-1.60 \mathrm{~g} / \mathrm{cm}^{3}\right)$. Water absorption in the fired pieces depended on the composition and particle size distribution of the raw materials. The highest values were found for the most carbonate-rich samples, while the lowest were recorded in marls with a low alkaline element content and a high proportion of the $<2 \mu \mathrm{m}$ fraction. In any event, the high linear shrinkage and water absorption in marls fired at 800 to $1,000{ }^{\circ} \mathrm{C}$ argue against the use of these materials to manufacture ceramic products (10).

With a view to improving drying and firing properties, the following blends were prepared with different proportions of commercial quartz and feldspars (Figure 10): A) $C A B-1-4+25 \%$ feldspars $+5 \%$ quartz; B) $C A B-$ $5+15 \%$ feldspars + $15 \%$ quartz; C) $C A B-7+15 \%$ feldespars $+5 \%$ quartz; D) $C A B-13+15 \%$ feldspars + $15 \%$ quartz. Fifteen per cent feldspars and fifteen per cent quartz were included in samples $C A B-5$ and $C A B-13$ 


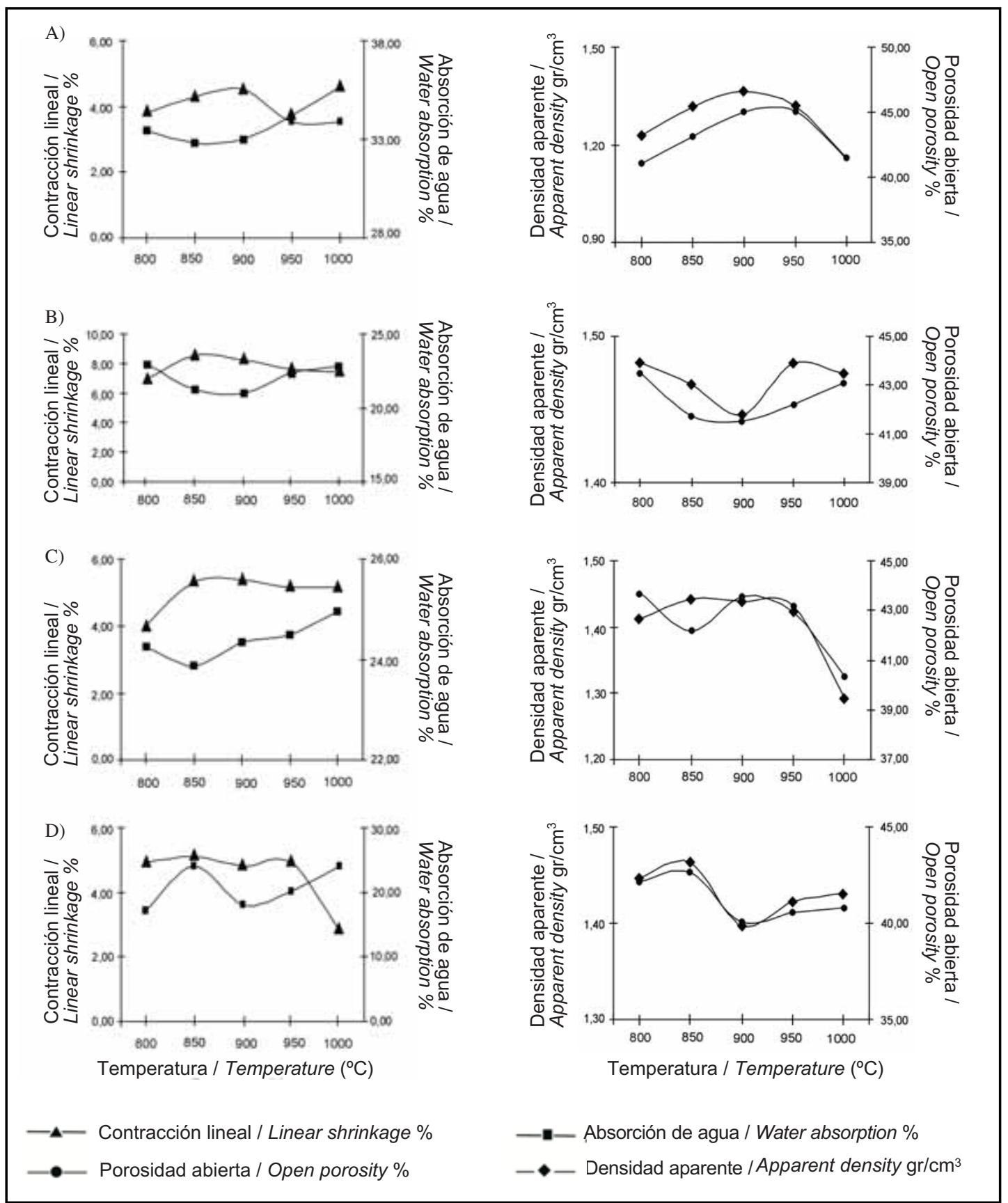

Figura 9. Ensayos de cocción de las margas de la Formación Carbonero. A) CAB-1-4; B) CAB-5; C) CAB-7; D) CAB-13. Figure 9. Firing trials with Carbonero Formation marls. A) $C A B-1-4$; B) $C A B-5$; C) $C A B-7$; D) $C A B-13$.

$15 \%$ de cuarzo para tratar de rebajar la contracción lineal y la absorción de agua. Sin embargo, la muestra CAB-1-4 fue mezclada con un $25 \%$ de feldespatos y un $5 \%$ de cuarzo, ya que se pretendía disminuir, fundamentalmente, la absorción de agua. Los resultados demuestran que se consiguió una disminución de los valores de contracción lineal en seco y en cocido (< $0,5 \%$ y $\sim 2,5 \%$, respectivamente), si bien, los valores de absorción de agua permanecieron prácticamente invariables. to attempt to reduce linear shrinkage and water absorption. Sample CAB-1-4, in turn, was blended with $25 \%$ feldspars and 5\% quartz, essentially to lower water absorption. The findings showed that dry and fired linear shrinkage declined (to $<0.5 \%$ and $~ 2.5 \%$, respectively), while the water absorption values remained practically unchanged. 

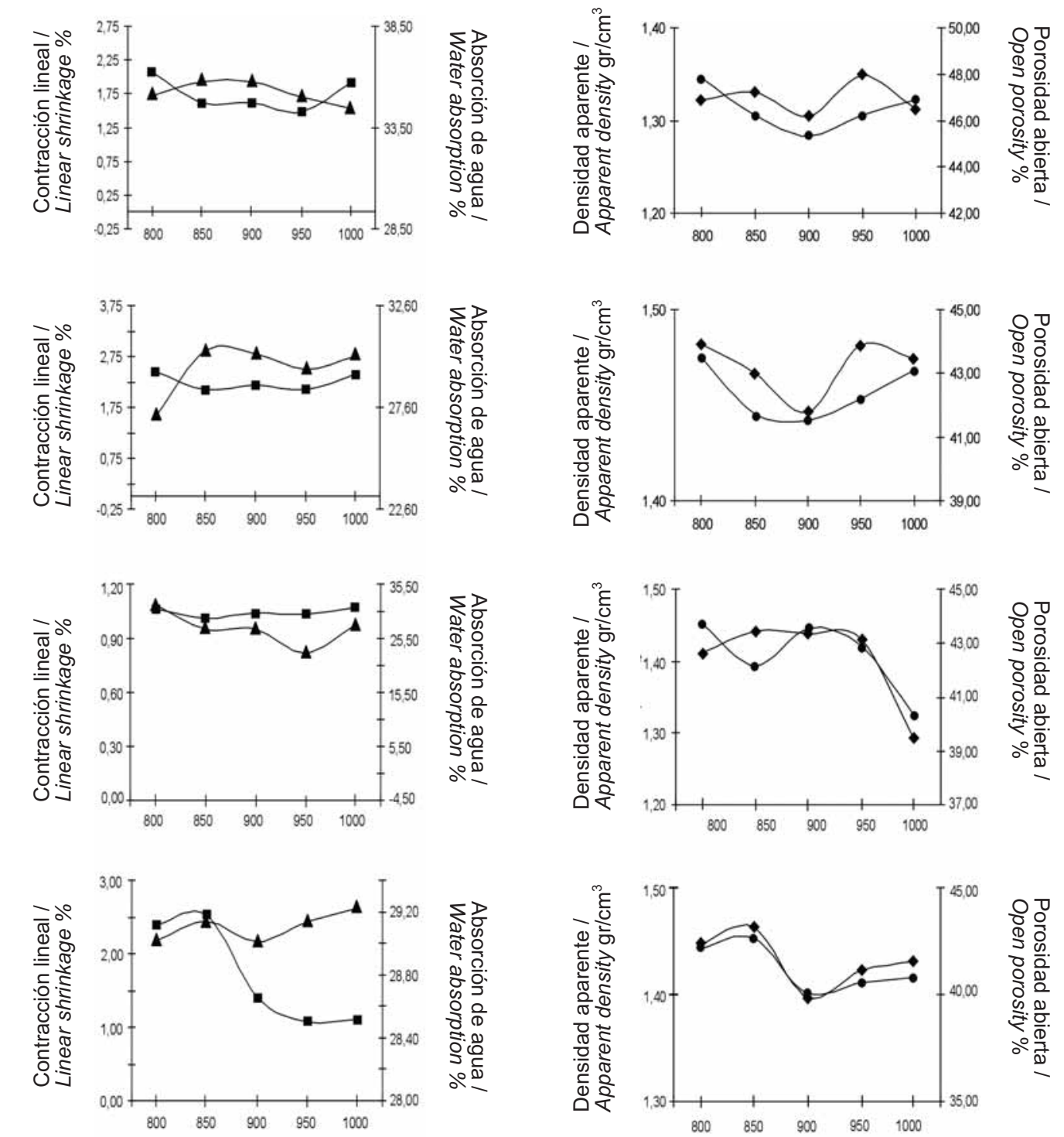

Temperatura / Temperature $\left({ }^{\circ} \mathrm{C}\right)$
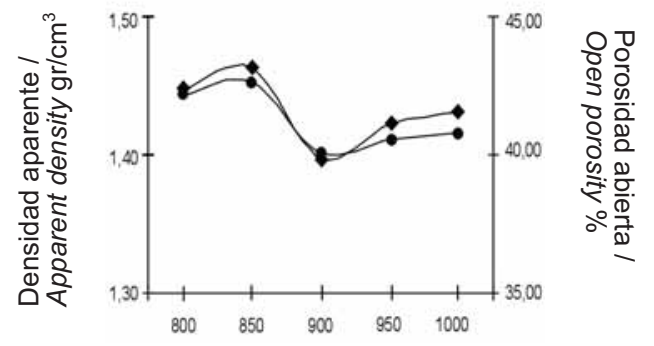

Temperatura / Temperature $\left({ }^{\circ} \mathrm{C}\right)$

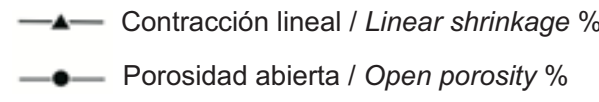

—- Absorción de agua / Water absorption \%
—— Densidad aparente / Apparent density $\mathrm{gr} / \mathrm{cm}^{3}$

Figura 10. Ensayos de cocción de las mezclas estudiadas. A) CAB-1-4 + 25\% Fds + 5\% Qtz; B) CAB-5 + 15 Fds $\%+15$ Qtz $\%$; C) CAB-7 + 15\% Fds + 5\% Qtz; D) CAB- $13+15 \%$ Fds $+15 \%$ Qtz.

Figure 10. Firing trials with blends studied. A) $C A B-1-4+25 \%$ Fds $+5 \%$ Qtz; B) CAB-5 + 15\% Fds + 15\% Qtz C) CAB-7 + $15 \%$ Fds $+5 \%$ Qtz; D) $C A B-13+15 \%$ Fds $+15 \%$ Qtz.

En cuanto al color de cocción, la mayoría de las muestras presentan tonos claros, principalmente debidos a sus bajas concentraciones en $\mathrm{Fe}_{2} \mathrm{O}_{3}$. Además, el $\mathrm{Fe}^{3+}$ es incorporado a la estructura de los silicatos de calcio formados durante la cocción (14). De esta forma, se impide la formación de hematites en las piezas cocidas.

Los minerales detectados en las piezas cocidas mediante DRX han sido wollastonita, gehlenita, anortita y cuarzo
In another vein, the post-firing colour of most of the samples was light, due primarily to their low $\mathrm{Fe}_{2} \mathrm{O}_{3}$ concentrations. Moreover, the $\mathrm{Fe}^{3+}$ uptake in the calcium silicates formed during firing (14) prevented haematites formation in the fired pieces.

XRD analysis detected wollastonite, gehlenite, anorthite and quartz in the fired pieces (Figure 11). This 


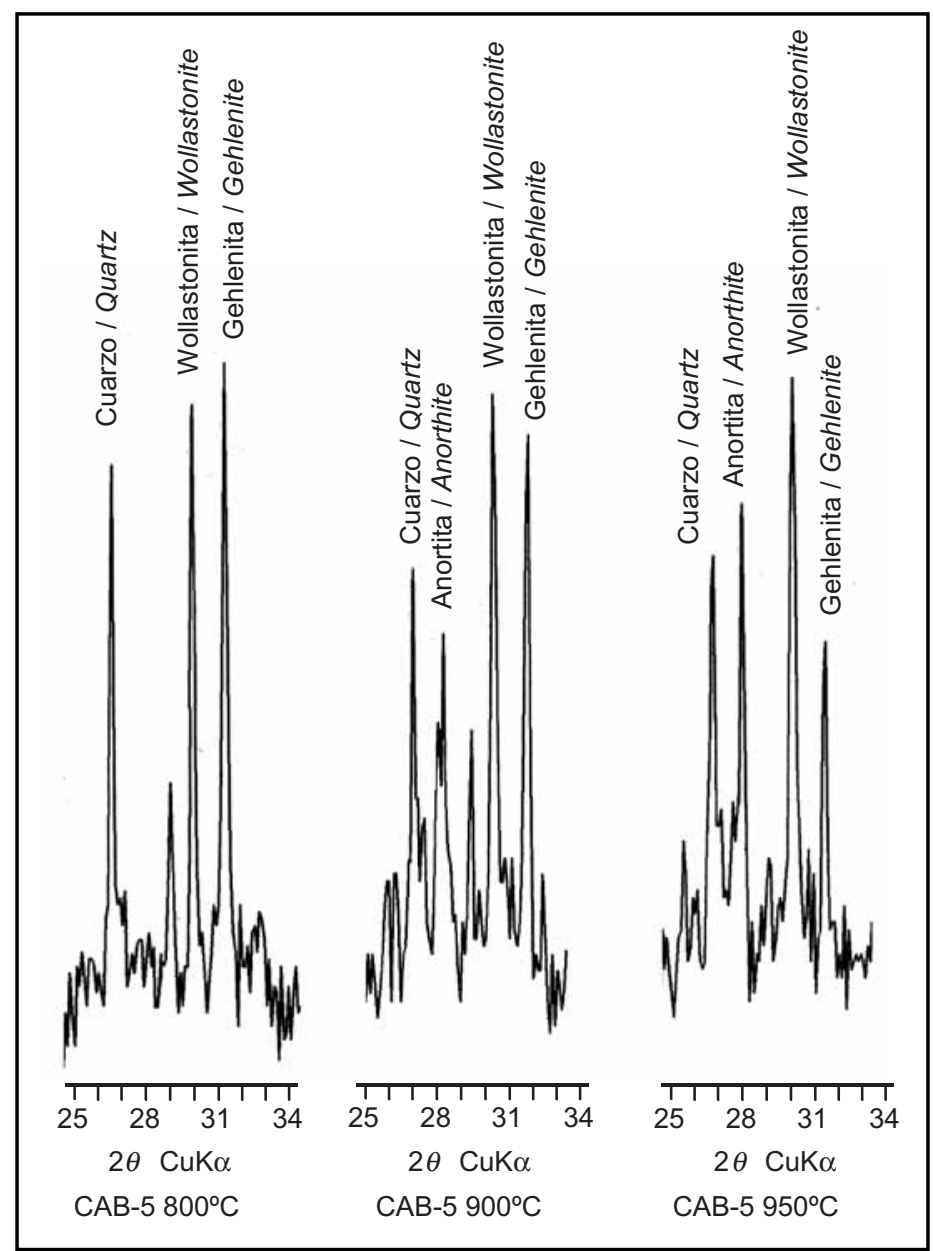

Figura 11. Difractogramas de la muestra $\mathrm{CAB}-5$ a $800{ }^{\circ} \mathrm{C}, 900{ }^{\circ} \mathrm{C}$ y $950^{\circ} \mathrm{C}$. Figure 11. Diffractogram for sample CAB-5 at 800, 900 and $950^{\circ} \mathrm{C}$.

(Figura 11). Esta asociación es similar a la previamente descrita por otros autores para materias primas con elevados contenidos en carbonatos $(15,16)$. La gehlenita y la wollastonita fueron detectadas a partir de los $800^{\circ} \mathrm{C}$ (Figura 11) y podrían haber sido formadas de acuerdo a las siguientes reacciones: association is consistent with other authors' descriptions of prime materials with high carbonate contents $(15,16)$. Gehlenite and wollastonite, detected at temperatures of $800^{\circ} \mathrm{C}$ or higher (Figure 11), may have formed as shown in the following reactions:

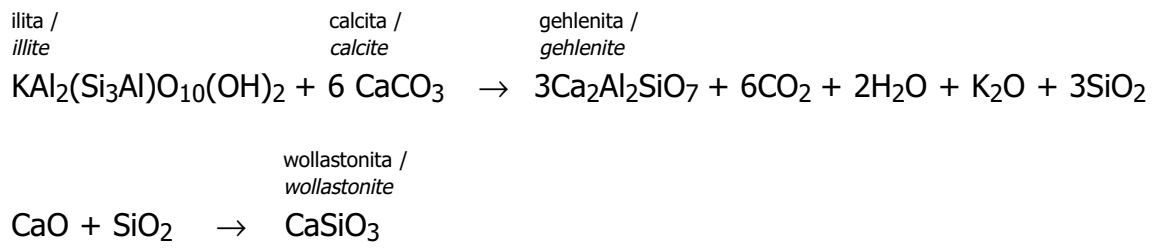

Por otra parte, la anortita se forma a partir de los $900{ }^{\circ} \mathrm{C}$ de acuerdo (Figura 11), probablemente, con la siguiente reacción:

Anorthite, in turn, formed at $900{ }^{\circ} \mathrm{C}$ or higher (Figure 11), probably as shown below:

$$
\begin{array}{llll}
\text { ilita I } & \text { calcita / } & \text { calcite } \\
\text { illite } & \begin{array}{l}
\text { sanidina / } \\
\text { sanidine }
\end{array} & \begin{array}{l}
\text { anortita / } \\
\text { anorthite }
\end{array} \\
\mathrm{KAl}_{2}\left(\mathrm{Si}_{3} \mathrm{Al}\right) \mathrm{O}_{10}(\mathrm{OH})_{2}+2 \mathrm{CaCO}_{3}+4 \mathrm{SiO}_{2} & \rightarrow \mathrm{kAllSi}_{3} \mathrm{O}_{8}
\end{array}+2 \mathrm{CaAl}_{2} \mathrm{SiO}_{8}+2 \mathrm{CO}_{2}+\mathrm{H}_{2} \mathrm{O}
$$

Esta reacción explicaría la disminución de la intensidad de la reflexión del cuarzo en las muestras estudiadas. Sin
This reaction would explain the decline in the intensity of the quartz reflection in the samples studied. Sanidine 
embargo, no se ha detectado mediante DRX la formación de sanidina, lo cual puede ser debido a la formación de una fase amorfa con composición similar a la de este mineral.

A partir de $950^{\circ} \mathrm{C}$ se ha observado la disminución del pico de la gehlenita (Figura 11), debido principalmente al comienzo de la reacción de desestabilización de este mineral para formar anortita y wollastonita. was not detected with XRD analysis, however, due perhaps to the formation of an amorphous phase with a similar composition.

The gehlenite peak declined after $950{ }^{\circ} \mathrm{C}$ (Figure 11), due primarily to the onset of its destabilization to form anorthite and wollastonite.

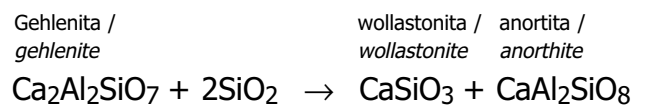

Las margas estudiadas de la Formación Carbonero se han representado en el diagrama de estabilidad Ca-SiAl (Figura 12). De acuerdo con este diagrama, las fases estables para la mayoría de las piezas cocidas son wollastonita, cuarzo y anortita. Sin embargo, en las muestras estudiadas ha sido detectada la formación local de gehlenita, formada por la presencia de importantes núcleos de $\mathrm{CaO}$ que reaccionan con las arcillas.
The marls studied in the Carbonero Formation are represented on a CA-Si-Al stability diagram in Figure 12. According to this diagram, the stable phases for most of the fired pieces were wollastonite, quartz and anorthite. In the samples studied, gehlenite was also observed to form locally as a result of the presence of large $\mathrm{CaO}$ clusters that reacted with the clays.

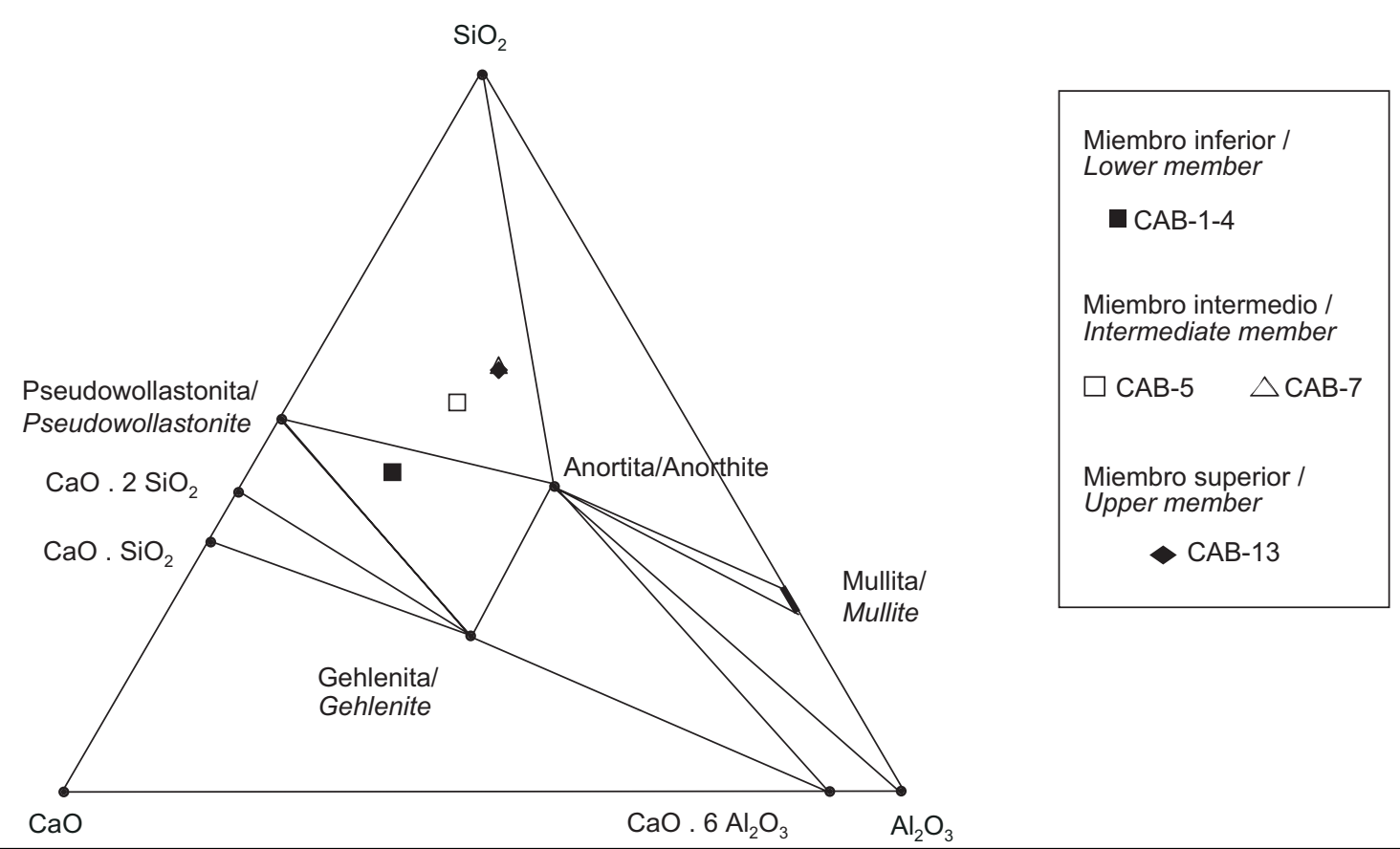

Figura 12. Posición de las margas estudiadas de la Formación Carbonero en el diagrama $\mathrm{CaO}-\mathrm{SiO}_{2}-\mathrm{Al}_{2} \mathrm{O}_{3}$. Figure 12. Position of Carbonero Formation samples in the $\mathrm{CaO}-\mathrm{SiO}_{2}-\mathrm{Al}_{2} \mathrm{O}_{3}$ system.

\section{CONCLUSIONES}

Las margas de la Formación Carbonero presentan características composicionales similares a las materias primas utilizadas en la industria cerámica. El bajo contenido en óxidos de hierro explica el desarrollo de un color claro durante la cocción. También, la distribución granulométrica de estos materiales es apropiada para la manufactura de productos de cerámica estructural.

\section{CONCLUSIONS}

Compositionally speaking, Carbonero Formation marls are similar to other prime materials used in the ceramic industry. Their low Fe oxide content explains the light colours observed after firing. The particle size distribution of these materials is likewise suitable for manufacturing structural ceramic products. 
Desde un punto de vista tecnológico, las margas de la Formación Carbonero son exclusivamente moldeables por prensado, debido a su baja plasticidad. Los altos valores de contracción lineal durante el secado y de las propiedades de cocción sugieren que las margas de la Formación Carbonero deben ser mezcladas con otros materiales para la fabricación de piezas cerámicas. En este sentido, las mezclas de esta materia prima con cuarzo y feldespatos mejoran la contracción lineal en seco y las propiedades de cocción para la elaboración de baldosas prensadas de color claro entre 800 y $1.000{ }^{\circ} \mathrm{C}$.

\section{AGRADECIMIENTOS}

Los autores han obtenido la financiación para llevar a cabo este trabajo a través de la Junta de Andalucía (Grupo de investigación RNM-325) y la Excelentísima Diputación Provincial de Jaén, mediante el proyecto de Investigación "Posibilidades de uso cerámico de los minerales y rocas industriales de la provincia de Jaén". Agradecemos a J. M. Molina y Ginés A. de Gea su ayuda en el trabajo de campo. C. Laurin revisó la versión inglesa de este trabajo.
From the technological standpoint, Carbonero Formation marls are press-mouldable only, due to their low plasticity. High dry linear shrinkage and firing property values suggest that the Carbonero Formation marls should be blended with other materials to manufacture ceramic products. In this regard, when blended with quartz and feldspars, this material exhibits a substantial reduction in dry linear shrinkage and firing properties apt for manufacturing light coloured pressed tiles at temperatures of from 800 to $1000^{\circ} \mathrm{C}$.

\section{ACKNOWLEDGEMENTS}

This study was funded by the Regional Government of Andalusia (Research Group RNM-325) and the Central Government's Provincial Representation in Jaén under the research project "Possibilities of using the province of Jaén's industrial minerals and rocks for ceramics". The authors wish to thank J. M. Molina and Ginés A. de Gea for their assistance with the field work. C. Laurin revised a prior English version of this paper.

\section{BIBLIOGRAFÍA / BIBLIOGRAPHY}

(1) González, I.: "Arcillas comunes", en García Guinea, J. y Martínez Frías, J. (eds.): Recursos minerales de España, Consejo Superior de Investigaciones Científicas, Madrid (1992), pp. 95-82.

(2) Díaz Rodríguez, L. A.; Torrecillas, R.: "Ceramic clays: a review of their different types, meaning and applicatios", Bol. Soc. Esp. Cerám. Vidrio, vol. 41 (2002), pp. 459-470.

(3) Fabbri, B.; Fiori, C.: "Clays and complementary raw materials for stoneware tiles", Mineral. Petrol. Acta, vol. 29 (1985), pp. 535-545.

(4) Moore, M. D.; Reynolds, R. C.: X-ray diffraction and the identification and analysis of clay minerals, Oxford University Press (1989), $332 \mathrm{pp.}$

(5) Dinelli, E.; Tateo, T.: "Sheet silicates as effective carries of heavy metals in the ophiolitic mine area of Vigonzano (northern Italy)", Mineralogical Magazine, vol. 65 (2001), pp. 121-132. doi:10.1180/002646101550172

(6) López-Galindo, A.: Las facies oscuras del Cretácico medio en la Zona Subbética. Mineralogía y sedimentación, Ph. D., Thesis, Univ. Granada, Spain (1986).

(7) Molina, J. M.; De Gea, G. A.; Aguado, R.: "Facies anóxicas, radiolaríticas y turbidíticas en el Cretácico de la Zona Subbética: la Formación Carbonero", en Ruiz-Ortiz, P. A.; Molina, J. M.; Nieto, L. M.; Castro, J. M.; De Gea, G. A. (eds.): Itinerarios geológicos por el Mesozoico de la provincia de Jaén (2001), pp. 39-60.

(8) Dondi, M.; Fabbri, B.; Laviano, R.: "Characteristics of the clays utilized in the bricks industry in Apulia and Basilicata (southren Italy)", Miner. Petrogr. Acta, vol. 35 A (1992), pp. 179-189.

(9) Fiori, C.; Fabbri, B.; Donati, F.; Venturi, I.: "Mineralogical composition of the clay bodies used in the Italian tile industry", Appl. Clay Sci., vol. 4 (1989), pp. 461-473. doi:10.1016/0169-1317(89)90023-9

(10) Fabbri, B.; Dondi, M.: La produzione del laterizio in Italia, Faenza Editrice (1995), p. 160.

(11) Winkler, H. G. F.: "Bedeutung der Korngrössenverteilung und des Mineralbestandes von Tonen für die herstellung grobkeramischer Erzeugnisse", Ber. Dtsch. Keram. Ges, vol. 31, no 10 (1954), pp. 337-343.

(12) Dondi, M.: "Clay materials for ceramic tiles from Sassuolo District (Northern Apenninrs, Italy). Geology, composition and technological properties", Appl. Clay Sci., vol. 5 (1999), pp. 337-366. doi:10.1016/S0169-1317(99)00027-7

(13) Bain, J. A.; Highley, D. E.: Regional appraisal of clay resources. A challenge to the clay mineralogist, Proc. Int. Clay Conf. AIPEA, Oxford (1966), pp. 437-447.

(14) Kreimeyer, R.: "Some notes on the firing colour of clay bricks", Appl. Clay Sci., vol. 2 (1987), pp. 175-183. doi:10.1016/01691317(87)90007-X

(15) González García, F.; Romero Acosta, V.; García Ramos, G.; Rodríguez González, M.: "Firing transformation of mixtures of clays containing ilite, kaolinite and calcium carbonate used by ornamental tile industry", Appl. Clay Sci., vol. 2 (1990), pp. 97-100.

(16) Cultrone, G.; Rodríguez Navarro, C.; Sebastián, E.; Cazalla, O.; De la Torre, M. J.: "Carbonate and silicate phase reactions during ceramic firing"; Eur. J. Mineral, vol. 13 (2001), pp. 621-634. doi:10.1127/0935-1221/2001/0013-0621 